\title{
EVIDENCE THAT LEPTOSPIRAL LIPOPOLYSACCHARIDE IS NOT AN IMPORTANT PROTECTIVE ANTIGEN
}

\author{
B. AdLeR AND S. FAINE \\ Department of Microbiology, Monash University, Clayton 3168, Melbourne, Australia
}

\begin{abstract}
SUMmary. CBA/N mice, which could not produce antibodies against lipopolysaccharide (LPS) from either Escherichia coli or Leptospira interrogans serovar pomona, produced levels of agglutinating antibodies against leptospires similar to those produced by immunologically normal CBA mice. CBA/N mice were thus resistant to acute leptospiral infection and $\mathrm{CBA} / \mathrm{N}$ immune serum passively protected immunosuppressed mice from infection. The results suggest that antibodies against LPS are not important in protection against experimental leptospiral infection in mice.
\end{abstract}

\section{INTRODUCTION}

Amsbaugh et al. (1972) reported that the CBA/N inbred mouse strain fails to produce antibodies against pneumococcal polysaccharide. Subsequent studies (Scher et al., 1975; Cohen, Scher and Mosier, 1976; Gershon and Kondo, 1976) showed that this trait is a sex-linked characteristic carried on the $\mathrm{X}$ chromosome and that these mice are unable to respond to a number of T-independent antigens. Scher, Zaldivar and Mosier (1977) showed that CBA/N mice are unresponsive to lipopolysaccharide (LPS) from Escherichia coli O111.

The LPS component is frequently the target site for the action of protective antibody on gram-negative bacteria (Weidanz, Jackson and Landy, 1964; Neoh and Rowley, 1970). Faine, Adler and Ruta (1974) reported that LPS extracted from leptospires protected Australian hopping mice from infection if it was injected with Freund's adjuvant, but Pleško (1975) found only very slight protective activity when LPS was used to immunise hamsters. Subsequently, Adler and Faine (1978) found that rabbit antisera against leptospiral LPS protected hamsters from infection only if agglutinins were concomitantly present. Antisera possessing only anti-LPS antibodies detectable by passive haemagglutination (HA) did not protect hamsters.

The aim of this study was to investigate the importance, if any, of LPS in the stimulation of protective antibodies and to determine whether CBA/N mice, which cannot respond to LPS, differ in their susceptibility to leptospiral infection from mice that can respond normally to LPS.

\section{MATERIALS AND METHODS}

Leptospires, sera and serological methods. Methods for culturing and counting Leptospira interrogans serovar pomona and for producing rabbit antiserum to pomona were described previously (Adler and Faine, 1976, 1978). LPS was extracted from leptospires and from E.coli O111 by the hot-phenol method of Westphal, Luderitz and Bister (1952). Rabbit antiserum against E. coli was prepared as described by Edwards and Ewing (1962). The methods for the microscopic agglutination test (MAT) and methods for sensitising sheep erythrocytes with leptospiral LPS for HA studies have been described (Faine, Adler and Palit, 1974; Adler and Faine, 1976), and the same methods were used in tests with E. coli LPS.

Animals. CBA and Balb/c mice were obtained from the Monash University, and CBA/N mice by courtesy of Professor I. McKenzie, Department of Medicine, Melbourne University, and bred at Monash University. Mice were infected with an intraperitoneal (IP) injection of 
$4 \times 10^{8}$ leptospires in $1 \mathrm{ml}$ of medium. They were immunised with $E$. coli by injecting $0 \cdot 1,0 \cdot 2$ and $0.3 \mathrm{ml}$ of boiled $E$. coli culture intraperitoneally on three occasions at 5 -day intervals, and were bled 5 days after the final injection. All mice were bled from the orbital plexus. Mice were immunosuppressed with cyclophosphamide as described previously (Adler and Faine, 1976), and those that were passively immunised were given $0.4 \mathrm{ml}$ of serum IP $1 \mathrm{~h}$ before infection.

\section{RESULTS}

Groups of eight CBA and CBA/N mice were infected with leptospires of serovar pomona. No deaths occurred within the observation period of 14 days. Both mouse strains produced antibodies detectable by MAT against leptospires, but $\mathrm{CBA} / \mathrm{N}$ mice produced slightly lower levels and antibody was first detected a day later than in CBA mice (figure). Balb/c mice are

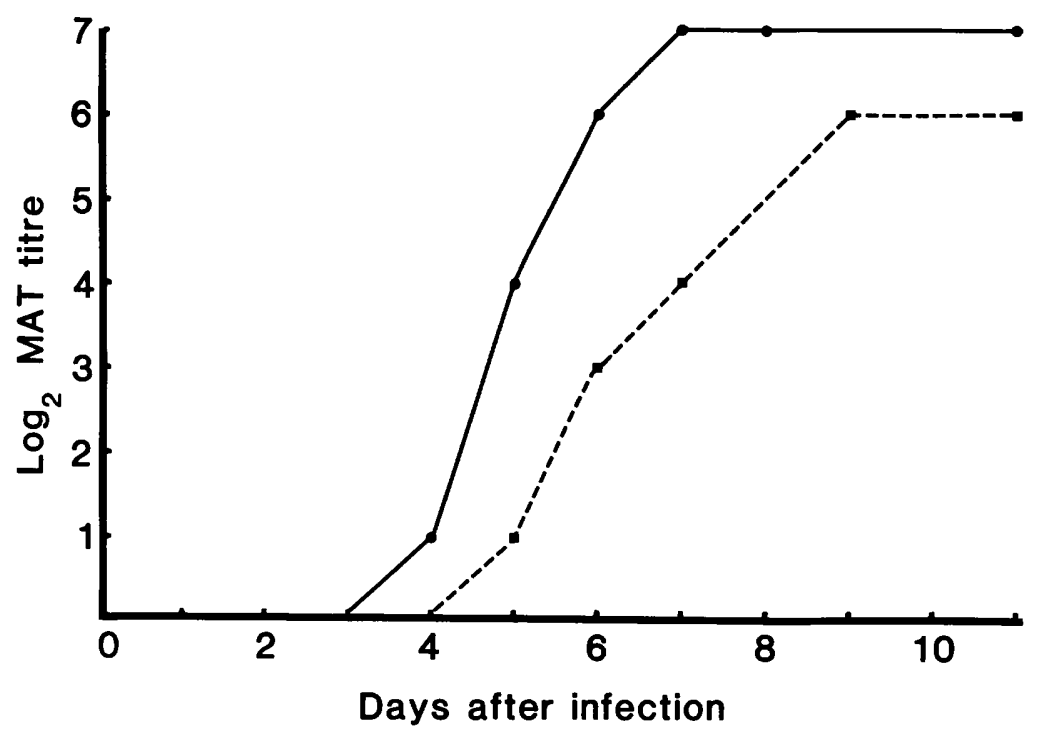

FIGURE. The agglutinating-antibody response to challenge with $4 \times 10^{8}$ leptospires of Leptospira interrogans serovar pomona in $\mathrm{CBA} / \mathrm{N}$ mice (-- - ) and in immunologically normal $\mathrm{CBA}$ mice $(\bullet-)$, assessed by a microscopic agglutination test (MAT, see Methods).

susceptible to infection only if immunosuppressed (Adler and Faine, 1976). To ascertain whether these $\mathrm{CBA}$ and $\mathrm{CBA} / \mathrm{N}$ strains of mice were similarly innately susceptible to infection if their capacity to produce antibody was suppressed, groups were treated with cyclophosphamide $48 \mathrm{~h}$ before infection IP with $4 \times 10^{8}$ leptospires of serovar pomona. Seven out of eight CBA and 8 of $8 \mathrm{CBA} / \mathrm{N}$ mice died within 6 days of infection and the autopsy findings indicated that death resulted from acute leptospirosis.

Both mouse strains were tested for their ability to produce antibodies, detectable by passive HA, against LPS extracted from either serovar pomona or E. coli O111. The results (table) showed that $\mathrm{CBA} / \mathrm{N}$ mice did not produce antibodies against either of the LPS preparations whereas CBA mice responded to both.

Immune serum taken from $\mathrm{CBA} / \mathrm{N}$ mice 7 days after infection was tested for its passive protective ability in immunosuppressed $\mathrm{CBA} / \mathrm{N}$ mice. All of five immunosuppressed infected mice died of acute leptospirosis, but no deaths occurred among five mice that received CBA/N immune serum $1 \mathrm{~h}$ before challenge. 
TABLE

The antibody titres, measured by passive haemagglutination, of $C B A, C B A / N$ or Balb/c mice against LPS extracted from either L. interrogans serovar pomona or E. coli O111*

\begin{tabular}{l|cc}
\hline \multirow{2}{*}{$\begin{array}{c}\text { Antiserum from } \\
\text { mouse strain }\end{array}$} & $\begin{array}{c}\text { Haemagglutination titre against homologous } \\
\text { lipopolysaccharide antigen after immunisation } \\
\text { with }\end{array}$ \\
\cline { 2 - 3 } & 16 & E. coli \\
\hline CBA & 16 & 32 \\
Balb/c & 0 & 32 \\
CBA/N & 1024 & 0 \\
Rabbit antiserum against & 0 & 0 \\
serovar pomona & & 128 \\
E. coli & & \\
\hline
\end{tabular}

* Mice were immunised with either organism as described in Materials and methods.

\section{Discussion}

$\mathrm{CBA} / \mathrm{N}$ mice have a defect that affects a late-developing subpopulation of $\mathrm{B}$ cells; this appears to be independent of $\mathrm{T}$ cells and of macrophages and it abolishes the humoral immune response of the mice to bacterial LPS (Scher et al., 1977). Thus these mice are more susceptible to infections in which antibody to LPS is important in protection. For example, CBA/N mice are a thousandfold more susceptible than genetically similar immunologically normal mice to Salmonella typhimurium infection (O'Brien et al., 1979). CBA/N mice are also more susceptible to murine malaria, in which the B cell is important in protection from infection (Hunter et al., 1979; Jayawardena, Janeway and Kemp, 1979).

It is therefore interesting that $\mathrm{CBA} / \mathrm{N}$ mice proved to be just as resistant to leptospiral infection as immunologically normal CBA mice, and produced almost equivalent levels of agglutinating antibody in our study. The importance of the early production of specific antibody in enabling mice to resist a primary leptospiral infection was shown by Adler and Faine (1977); the appearance of agglutinins by the fifth day after infection of CBA/N mice is apparently early enough to halt the infection. Subagglutinating levels of antibody probably appear within about 3 days, by analogy with observations made on Balb/c mice, in which low levels of opsonising antibody were detected 1-2 days before agglutinating activity was demonstrable in the serum. The fact that $\mathrm{CBA} / \mathrm{N}$ mice are susceptible to acute infection when their humoral immunity is suppressed by cyclophosphamide supports the conclusion that their resistance is attributable to their ability to produce early specific antibodies and not due to other unknown genetic factors.

The CBA/N mice did not produce antibodies to LPS from either leptospires or $E$. coli although $\mathrm{CBA}$ and Balb/c mice did so and the HA detection system was verified with control rabbit antisera. Despite the lack of anti-LPS antibodies, CBA/N immune sera passively protected mice from acute infection. We can therefore conclude that antibodies to LPS are not necessary to protect mice from leptospiral infection and that the LPS in the form used as a detecting antigen for antibody in these experiments is not a protective antigen. The nature of the protective antigen in leptospires remains undetermined, but appears to differ from that of many other gram-negative bacteria against which LPS is an important protective antigen.

Similarly, the nature of the antigen or antigens participating in the agglutination of leptospires by immune sera is not known, although Chang and Faine (1973) suggested that the axial filament was involved in agglutination. However our studies, in which CBA/N mice produced levels of agglutinating antibody comparable with those in normal mice, suggest that LPS is not a major agglutinating antigen in leptospires. This contention is supported by our 
earlier finding that specific anti-LPS antiserum reacted with but did not agglutinate leptospires (Adler and Faine, 1978).

This work was supported by a grant from the National Health and Medical Research Council, Canberra, Australia.

\section{REFERENCES}

AdLER, B. AND FAINE, S. 1976. Susceptibility of mice treated with cyclophosphamide to lethal infection with Leptospira interrogans serovar pomona. Infect. Immun. 14, 703.

AdLeR, B. AND FaINE, S. 1977. Host immunological mechanisms in the resistance of mice to leptospiral infections. Infect. Immun., 17, 67.

AdLeR, B. AND FAINE, S. 1978. Serological and protective antibody responses of rabbits to leptospiral antigens. J. med Microbiol., 11, 401.

Amsbaugh, D. F., Hansen, C. T., Precott, B., Stashak, P. W., Barthold, D. R. and Baker, P. J. 1972. Genetic control of the antibody response to type III pneumococcal polysaccharide in mice. I. Evidence that an X-linked gene plays a decisive role in determining responsiveness. J. exp. Med., 136, 931 .

ChANG, A. AND FaINE, S. 1973. Effect of anti-cell and anti-axial filament sera on Leptospira. Aust. J. exp. Biol. med. Sci., 51, 847.

COHEN, P. L., SCHER, I. AND Mosier, D. E. 1976. In vitro studies of the genetically determined unresponsiveness to thymus-independent antigens in CBA/N mice. J. Immun., 116, 808.

EDWARDS, P. R. AND EWING, W. H. 1962. Identification of Enterobacteriaceae, 2nd ed., Burgess Publishing Company, Minnesota.

Faine, S., Adler, B. AND Palit, A. 1974. Chemical, serological and biological properties of a serotype-specific polysaccharide antigen in Leptospira. Aust. J. exp. Biol. med. Sci., 52, 311.

Faine, S., Adler, B. and Ruta, G. 1974. A mechanism of immunity to leptospirosis. Aust. J. exp. Biol. med Sci., 52, 301.

GeRSHON, R. K. AND Kondo, K. 1976. Deficient production of a thymus-dependent high affinity antibody subset in mice (CBA/N) with an X-linked B-lymphocyte defect. J. Immun., 117,701 .

Hunter, K. W., Finkelman, F. D., Strickland, G. T., Sayles, P. C. and Scher, I. 1979. Defective resistance to Plasmodium yoellii in CBA/N mice. J. Immun., 123, 133.

Jayawardena, A. N., Janeway, C. A. And Kemp J. D. 1979. Experimental malaria in the CBA/N mouse. J. Immun., 123, 2532.

NeOH, S. H. AND RowleY, D. 1970. The antigens of Vibrio cholerae involved in the vibriocidal action of antibody and complement. J. infect. Dis., 121, 505.

O’Brien, A. D., Scher, I., Campbell, G. H., MacDermott, R. P. and Formal, S. B. 1979. Susceptibility of CBA/N mice to infection with Salmonella typhimurium: influence of the $\mathrm{X}$-linked gene controlling B lymphocyte function. J. Immun., 123, 720.

PLEŠKO, I. 1975. Immunogenic activity of some leptospiral extracts. Proceedings of national symposium on leptospirosis, Leptospira and other Spirochaeta, Bucharest 1975, Editura Medicală, Bucharest.

Scher, I., Steinberg, A. D., Berning, A. K. and Paul, W. E. 1975. X-linked B-lymphocyte immune defect in $\mathrm{CBA} / \mathrm{N}$ mice. II. Studies of the mechanisms underlying the immune defect. J. exp. Med., 142, 637.

SCHER, I., Zaldivar, N. M. AND Mosier, D. E. 1977. B-lymphocyte subpopulations and endotoxin response in CBA/N mice. In Microbiology 1977, edited by D. Schlessinger, ASM Publications, Washington DC, p. 310.

WEIDANZ, W. P., JACKSON, A. L. AND LANDY, M. 1964. Some aspects of the antibody response of rabbits to immunization with Enterobacterial somatic antigens. Proc. Soc. exp. Biol. Med., 116, 832.

WestPhal, O., Luderitz, O. AND BISTER, F. 1952. Über die Extraktion von Bakterien mit Phenol Wasser. Z. Naturf. B., 7, 148. 